\title{
PENGARUH PENJUALAN TUNAI DAN PENJUALAN KREDIT TERHADAP LABA PADA INDUSTRI BENGKEL LAS DIANA DI PALOPO
}

\author{
Pasoni Mustafa Muhani1 \\ Sumiati
}

No. HP $085242438738^{1}$

\begin{abstract}
ABSTRAK
Penelitian ini bertujuan Untuk mengetahui dan menganalisis dengan menaikkan penjualan tunai atau penjualan kredit meningkatkan laba pada Industri Bengkel Las Diana di Palopo.

Hasil uji $F$ menunjukkan bahwa nilai $F$ hitung 3,733 dengan tingkat signifikansi 0,000 lebih kecil dari 0,05 (tabel 2,32) hal ini menunjukkan bahwa yaitu penjualan tunai dan penjualan kredit secara serentak atau bersma-sama berpengaruh positif dan signifikan terhadap laba usaha dengan demikian hipotesis diterima.

Nilai koefisien korelasi (R) sebesar 88,8\%, hal ini menunjukkan bahwa hubungan antara variabel bebas yaitu penjualan tunai dan penjualan kredit terhadap variabel terikat yaitu laba Usaha (Y) berkorelasi positif atau mempunyai hubungan yang kuat.

Nilai koefisien determinasi $\left(R^{2}\right)$ sebesar 0,789 menunjukkan bahwa pengaruh atau kontribusi variabel bebas terhadap variabel terikat sebesar $78,9 \%$ dan sisanya sebesar 21,10\% dipengaruhi oleh faktor atau variabel lain yang tidak diteliti dalam penelitian ini
\end{abstract}

Kata Kunci: Penjualan Tunai, Penjualan kredit dan laba.

\section{PENDAHULUAN}

Kemajuan ilmu pengetahuan dan teknologi dewasa ini dengan berkembangnya dunia usaha dan semakin banyaknya perusahaan-perusahaan besar, maka faktor keuangan mempunyai arti yang sangat penting. Untuk mengetahui kondisi keuangan perusahaan, harus mempunyai data laporan keuangan setiap tahun atau setiap periode akuntansi yang bersangkutan. Bagi perusahaan itu sendiri, Pengaruh terhadap keadaan keuangannya akan dapat membantu perusahaan tersebut untuk dapat melihat posisi keuangannya sehingga dapat membantu perusahaan dalam melakukan perencanaan keuangan. Akan tetapi setiap rencana yang baik, haruslah berhubungan dengan kekuatan dan kelemahan dari perusahaan tersebut.

Setiap perusahaan didirikan pada umumnya bertujuan untuk memperoleh laba. Kemampuan suatu perusahaan untuk menghasilkan laba, selama periode tertentu, dapat dilihat pada laporan laba rugi perusahaan yang bersangkutan. Dari laba yang dihasilkan suatu perusahaan, jika dibandingkan dengan yang digunakan akan menentukan pada level mana kondisi rentabilitas perusahaan tersebut. Untuk itu, maka perusahaan harus menggunakan dana yang ada untuk menghasilkan laba yang maksimal. Adanya kegagalan perusahaan dalam kegiatan usahanya, karena dana yang tersedia tidak 
dimanfaatkan secara efektif dan efisien. Disamping berusaha untuk mendapatkan laba, perusahaan juga ingin agar kegiatan operasionalnya dapat berjalan dengan lancar. Oleh karena itu, maka perusahaan harus selalu memperhatikan hal-hal yang menyangkut kemampuan perusahaan tersebut untuk memenuhi kewajiban Finansialnya.

Suatu fungsi yang dianggap sebagai ujung tombak dalam suatu perusahaan karena fungsi itulah perusahaan memperoleh pendapatan yaitu sistem penjualan yang merupakan suatu kesatuan proses yang saling mendukung dalam usahanya untuk memenuhi kebutuhan pembeli dan bersama sama mendapatkan kepuasan dan keuntungan sedangkan Sistem penjualan tunai adalah sistem yang melibatkan sumber daya dalam suatu organisasi, prosedur, data, serta sarana pendukung untuk mengoperasikan sistem penjualan, sehingga menghasilkan informasi yang bermanfaat bagi pihak manajemen dalam pengambilan keputusan. Sistem penjualan tunai merupakan sistem yang dilakukan oleh perusahaan dengan cara mewajibkan pembeli melakukan pembayaran harga terlebih dahulu sebelum barang diserahkan oleh perusahaan kepada pembeli. setelah uang diterima perusahaan, barang kemudian diserahkan kepada pembeli dan transaksi penjualan tunai kemudian dicatat oleh perusahaan.

Cara pengelolan piutang/kredit Usaha Bengkel Las dilakukan setiap satu bulan penagihan atau 30 hari. Jika konsumen tersebut tidak melunasi tagihan dalam waktu yang ditentukan, masih diberikan penambahan waktu 1 bulan atau 30 hari. Jika dalam penambahan waktu tersebut belum bisa membayar tagihannya, maka perusahaan melakukan tindakan penarikan produk konsumen tersebut, Sehingga masalah piutang/kredit menjadi begitu penting dalam kaitannya dengan perusahaan manakala harus menentukan berapa besar jumlah piutang/kredit yang optimal.

Berdasarkan Undang - Undang No. 10 tahun 1998 tentang perubahan atas UU No. 7 tahun 1992 yang maksud dengan kredit adalah penyediaan uang atau tagihan yang dapat disamakan, berdasarkan persetujuan atau kesepakatan pinjam meminjam antar perusahaan dengan pihak lain yaitu mewajibkan pihak peminjaman untuk melunasi utangnya setelah jangka waktu tertentu.

\section{METODE PENELITIAN}

Penelitian ini dilaksanakan pada Industri Bengkel Las Diana di Palopo. Metode pengumpulan data terdiri dari penulisan pustaka, penelitian lapangan, dan dokumentasi. Adapun jenis data yang digunakan yaitu data kuantitatif dan data kualitatif. Sedangakan sumber datanya yaitu data primer dan data sekunder.

\section{Metode Analisis}

Untuk menganalisis data penelitian ini penulis menggunakan metode Statatistik dengan regressi linear 
berganda Sugiyono (2010: 224) sebagai berikut :

$Y=b_{0}+b_{1} X_{1}+b_{2} X_{2}+e_{i}$

\section{Dimana :}

$\mathrm{Y}=$ Laba

$\mathrm{X}_{1}=$ Penjualan Tunai (Rp)

$\mathrm{X}_{2}=$ Penjualan Kredit $(\mathrm{Rp})$

$\mathrm{B}_{1}, \mathrm{~B}_{2},=$ Koefisien regresi (parameter)

ei $=$ Konstanta (intercept)

\section{HASIL PENELITIAN DAN PEMBAHASAN}

\section{Deskripsi hasil Penelitian}

\section{Konsep Laba Usaha}

Secara umum laba merupakan sebagai jumlah yang berasal dari pengurangan harga pokok, biaya lain dan kerugian dari penghasilan atau penghasilan operasi atau pengambilan atas investasi kepada pemilik. Hal ini mengukur nilai yang dapat diberikan oleh entitas kepada investor dan entitas masih memiliki kekayaan yang sama dengan posisi awalnya. Sedangkan Laba Bersih merupakan perbedaan antara jumlah pendapatan yang diperoleh suatu satuan usahan selama periode tertentu dan jumlah biaya yang dapat diaplikasikan kepada pendapat. Kemudian menurut Belkaoui (1999) Laba merupakan suatu pos dasar dan penting dari ikhtisar keuangan yang merniliki berbagai kegunaan dalam berbagai konteks. Laba pada umumnya dipandang sebagai suatu dasar bagi perpajakan, determinan pada kebijakan pembayaran dividen, pedoman investasi, dan pengambilan keputusan, dan unsur prediksi.
Sedangkan menurut Rahmat (2006:9) Laba dipandang sebagai suatu peralatan prediktif yang membantu dalam peramalan laba mendatang dan peristiwa ekonomi yang akan datang. Laba terdiri dari hasil operasional, atau luar biasa, dan hasil-hasil non-operasional, atau keuntungan dan kerugian luar biasa, dimana jumlah keseluruhannya sama dengan laba bersih. Laba biasa dianggap bersifat masa kini (current) dan berulang, sedangkan keuntungan dan kerugian luar biasa tidak demikian.

Adanya persamaan pendapat untuk mendefinisikan laba secara tepat disebabkan oleh luasnya penggunaan konsep laba. Para pemakai laporan keuangan mempunyai konsep laba sendiri yang dianggap paling cocok untuk pengambilan keputusan mereka. Untuk lebih jelas berikut akan disajika laporan Laba Pada perusahaan Las Dianan di Palopo 
Tabel 1

Rekapitulasi hasil perhitungan Laba tahun 2009-2013

\begin{tabular}{|r|c|c|c|}
\hline \multirow{2}{*}{ Tahun } & Laba & \multicolumn{2}{|c|}{ Perubahan } \\
\cline { 3 - 4 } & & $\mathbf{R p})$ & $\mathbf{( \% )}$ \\
\hline 2009 & 30.600 .000 & - & - \\
\hline 2010 & 34.200 .000 & 3.600 .000 & 10,53 \\
\hline 2011 & 36.000 .000 & 1.800 .000 & 5,00 \\
\hline 2012 & 22.300 .000 & -13.700 .000 & $-61,43$ \\
\hline 2013 & 20.700 .000 & -1.600 .000 & $-7,73$ \\
\hline Jumlah & $\mathbf{1 4 3 . 8 0 0 . 0 0 0}$ & $\mathbf{- 9 . 9 0 0 . 0 0 0}$ & $\mathbf{- 5 3 , 6 4}$ \\
\hline Rata-Rata & $\mathbf{2 8 . 7 6 0 . 0 0 0}$ & $\mathbf{- 2 . 4 7 5 . 0 0 0}$ & $\mathbf{- 1 3 , 4 1}$ \\
\hline
\end{tabular}

Berdasarkan pada tabel satu di atas menjelaskan bahwa laba perusahaan per tahunnya mulai tahun 2009-2013 mengalami peningkatan yang cukup signifikan yaitu pada tahun 2009 sebesar Rp.30.600.000,- pada tahun 2010 sebesar Rp. 34.200.000,- pada tahun 2011 sebesar Rp.36.000.000,pada tahun 2012 sebesar Rp.22.300.000,pada tahun 2013 sebesar Rp. 20.700.000,atau rata-rata per tahunnya sebesar $\mathrm{Rp}$. 28.760.000,- Untuk lebih jelasnya dapat dilihat gambar grafik berikut:

\section{Gambar grafik: Laba}

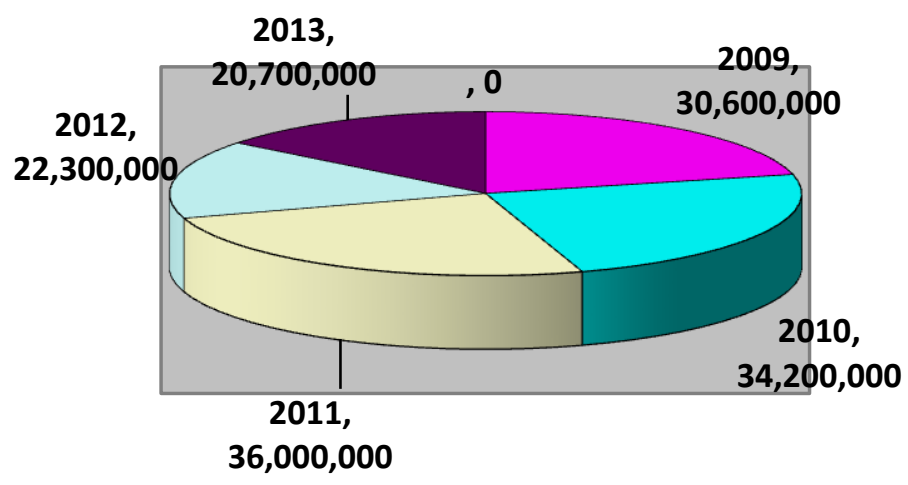




\section{Kosep Penjualan Tunai}

Penjualan tunai adalah sistem yang dilakukan oleh perusahaan dengan cara mewajibkan pembeli melakukan pembayaran harga terlebih dahulu sebelum barang diserahkan oleh perusahaan kepada pembeli oleh Usaha Bengkel Las Diana di Palopo. Untuk lebih jelasnya dapat dilihat pada tabel 2 berikut:

Tabel 2

Rekapitulasi hasil perhitungan Penjualan Tunai tahun 2009-2013

\begin{tabular}{|r|r|r|r|}
\hline \multirow{2}{*}{ Tahun } & Penjualan Tunai & \multicolumn{2}{|c|}{ Perubahan } \\
\cline { 3 - 4 } & & $\mathbf{( R p )}$ & $\mathbf{( \% )}$ \\
\hline $\mathbf{2 0 0 9}$ & 50.100 .000 & - & - \\
\hline $\mathbf{2 0 1 0}$ & 54.300 .000 & 4.200 .000 & $\mathbf{7 , 7 3 5}$ \\
\hline $\mathbf{2 0 1 1}$ & 56.200 .000 & 1.900 .000 & 3,381 \\
\hline $\mathbf{2 0 1 2}$ & 30.400 .000 & -25.800 .000 & $-84,87$ \\
\hline $\mathbf{2 0 1 3}$ & 35.600 .000 & 5.200 .000 & 14,61 \\
\hline Jumlah & $\mathbf{2 2 6 . 6 0 0 . 0 0 0}$ & $\mathbf{- 1 4 . 5 0 0 . 0 0 0}$ & $\mathbf{- 5 9 , 1 5}$ \\
\hline Rata-Rata & $\mathbf{4 5 . 3 2 0 . 0 0 0}$ & $\mathbf{- 3 . 6 2 5 . 0 0 0}$ & $\mathbf{- 1 4 , 7 9}$ \\
\hline
\end{tabular}

Berdasarkan pada tabel dua di Gambar grafik: Penjualan Tunai atas menjelaskan bahwa laba perusahaan per tahunnya mulai tahun 2009-2013 mengalami peningkatan yang cukup signifikan yaitu pada tahun 2009 sebesar Rp.50.100.000,- pada tahun 2010 sebesar Rp. 54.300.000,- pada tahun 2011 sebesar Rp. 56.000.000,- pada tahun 2012 sebesar Rp.30.400.000,- pada tahun 2013 sebesar Rp. 35.600.000,- atau rata-rata per tahunnya sebesar Rp. 45.320.000,- Untuk lebih jelasnya dapat dilihat gambar grafik

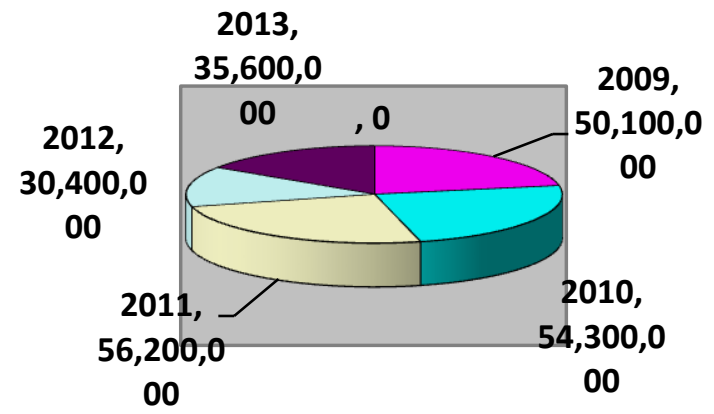
berikut: 


\section{Konsep Penjualan kredit}

Penjualan kredit merupakan suatu pinjaman yang diberikan kepada konsumen yang diharapkan dapat dikembalikan oleh konsumen dimasa yang akan datang. Berikut rekapitulasi hasil perhitungan pada tabel 2 sebagai berikut:

Tabel 3

Rekapitulasi hasil perhitungan Penjualan Kredit tahun 2009-2013

\begin{tabular}{|c|c|c|c|}
\hline \multirow{2}{*}{ Tahun } & \multirow{2}{*}{ Penjualan kredit } & $\mathbf{2}$ Perubahan \\
\cline { 3 - 4 } & 20.600 .000 & - & (\%) \\
\hline 2009 & 21.200 .000 & 600.000 & 2,830 \\
\hline 2010 & 23.000 .000 & 1.800 .000 & 7,826 \\
\hline 2011 & 14.300 .000 & -8.700 .000 & $-60,84$ \\
\hline 2012 & 13.100 .000 & -1.200 .000 & $-9,16$ \\
\hline 2013 & $\mathbf{9 2 . 2 0 0 . 0 0 0}$ & $\mathbf{- 7 . 5 0 0 . 0 0 0}$ & $\mathbf{- 5 9 , 3 4}$ \\
\hline Jumlah & $\mathbf{1 8 . 4 4 0 . 0 0 0}$ & $\mathbf{- 1 . 8 7 5 . 0 0 0}$ & $\mathbf{- 1 4 , 8 4}$ \\
\hline Rata-Rata & &
\end{tabular}

Berdasarkan pada tabel tiga di atas menjelaskan bahwa laba perusahaan per tahunnya mulai tahun 2009-2013 mengalami peningkatan yang cukup signifikan yaitu pada tahun 2009 sebesar Rp.20.600.000,- pada tahun 2010 sebesar Rp. 21.200.000,- pada tahun 2011 sebesar Rp. 23.000.000,- pada tahun 2012 sebesar Rp.14.300.000,- pada tahun 2013 sebesar Rp. 13.100.000,- atau rata-rata per tahunnya sebesar Rp. 18.440.000,- Untuk lebih jelasnya dapat dilihat gambar grafik berikut:

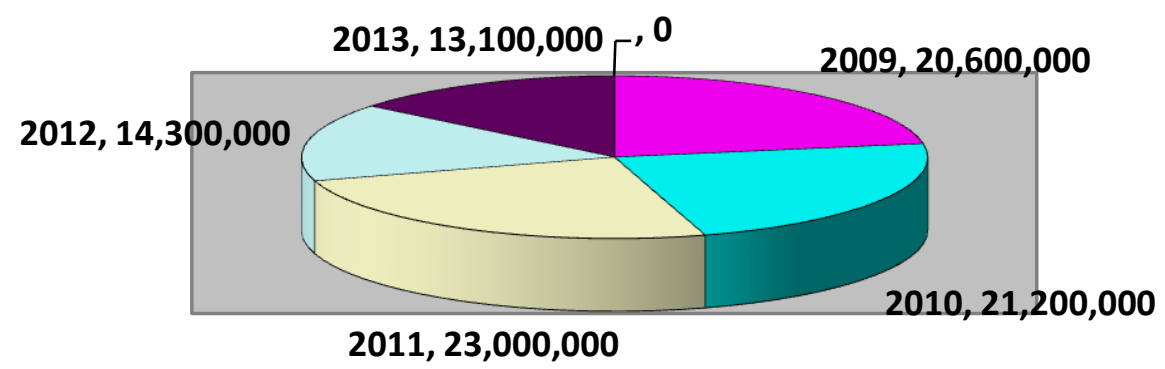




\section{Pembahasan}

Adapun metode yang digunakan dalam penulisan skripsi penelitian ini adalah metode analisis kuantitatif dengan penjelasan sebagai berikut:

Untuk mengetahui Pengaruh Penjulan tunai dan Penjualan Kredit terhadap Laba maka pengujian hipotesis dilakukan dengan menggunakan metode analisis regresi linear sederhana untuk menganalisis pengaruh antara variabel bebas terhadap variabel terikat dengan bantuan program Statistical Package for Social Science (SPSS). Hasil perhitungan analisis regresi linear sederhana dapat dilihat pada tabel 1 berikut ini:

Tabel 4

Hasil Analisis Regresi Linear berganda

\begin{tabular}{|l|l|c|c|c|c|c|}
\hline \multirow{2}{*}{ Model } & & \multicolumn{2}{|c|}{$\begin{array}{c}\text { Unstandardized } \\
\text { Coefficients }\end{array}$} & $\begin{array}{c}\text { Standardized } \\
\text { Coefficients }\end{array}$ & $\mathbf{t}$ & Sig. \\
\hline \multirow{2}{*}{1} & & B & Std. Error & Beta & & \\
\hline & (Constant) & 516.643 & 62.336 & &, 829 &, 494 \\
\hline & X1 & 8,348 & 9,622 & 1,262 & 8,676 &, 000 \\
\hline & X2 & 6,418 &, 995 & 2,072 & 7,425 &, 000 \\
\hline
\end{tabular}

Berdasarkan hasil analisis pada tabel 4 diatas, menunjukkan bahwa persamaan regreasi linear berganda dari penelitian ini adalah sebagai berikut :

$$
\begin{aligned}
& Y=b_{0}+b_{1} X_{1}+b_{2} X_{2}+e_{i} \\
& Y=516.643 b_{0}+8,348 X 1+6,418 X 2
\end{aligned}
$$

Berdasarkan persamaan regreasi linear berganda di atas, maka apabila diinterpretasikan dapat memberi pengertian analisa yaitu :

a. Nilai konstanta (b0) sebesar 516.643 menunjukkan bahwa apabila variabel bebas penjualan tunai (X1) dan penjualan kredit (X2) konstan atau sama dengan nol, maka laba usaha meningkat sebesar 516.643. b. Besarnya nilai koefisien regresi b1 adalah 8,348,- menunjukkan bahwa jika variabel penjualan tunai (X1) dapat ditingkatkan, maka akan meningkatkan laba usaha sebesar 83.48 dengan asumsi variabel lainnya yaitu $\mathrm{X} 2$ berada dalam keadaan konstan.

c. Besarnya nilai koefisien regresi b2 adalah 64.18 menunjukkan bahwa jika variabel penjualan kredit (X2) dapat ditingkatkan, maka akan meningkatkan laba usaha sebesar 64.18 dengan asumsi variabel lainnya yaitu $\mathrm{X} 1$ berada dalam keadaan konstan. 
Tabel 5

Summary

\begin{tabular}{l|r|r|r|r|}
\hline Model & $\mathrm{R}$ & R Square & Adjusted R Square & Std. Error of the Estimate \\
\hline 1 &, $888(\mathrm{a})$ &, 789 &, 577 & 220.943 \\
\hline
\end{tabular}

a. Nilai koefisien korelasi $(\mathrm{R})$ sebesar 0.888 $\mathrm{X} 100=88,8 \%$, hal ini menunjukkan bahwa hubungan antara variabel bebas yaitu penjualan tunai ( $\mathrm{X} 1$ dan penjualan kredit (X2) terhadap variabel terikat yaitu laba Usaha (Y) berkorelasi positif atau mempunyai hubungan yang kuat karena mendekati angka 1. b. Nilai koefisien determinasi $\left(R^{2}\right)$ sebesar $0,789 \times 100 \%=78,9$ menunjukkan bahwa pengaruh atau kontribusi variabel bebas terhadap variabel terikat sebesar $78,9 \%$ dan sisanya sebesar $21,10 \%$ dipengaruhi oleh faktor atau variabel lain yang tidak diteliti dalam penelitian ini seperti jumlah konsumen dan kualitas pelayanan

Tabel 6

ANOVA (b)

\begin{tabular}{|c|l|c|c|c|c|c|}
\hline Model & & $\begin{array}{c}\text { Sum of } \\
\text { Squares }\end{array}$ & df & Mean Square & $\mathrm{F}$ & Sig. \\
\hline 1 & Regression & 3,6445 & 2 & 1.822 .267 & 3,733 &, $000(\mathrm{a})$ \\
\hline & Residual & 9,7631 & 2 & 4.881 .585 & & \\
\hline & Total & 4,6208 & 4 & & & \\
\hline
\end{tabular}

a Predictors: (Constant), X2, X1

b Dependent Variable: $Y$

1. Analisis uji $\mathbf{F}$ dilakukan untuk melihat secara simultan pengaruh variabel bebas yaitu penjulan tunai dan penjulan kredit (X1 dan X2) terhadap variabel terikat yaitu laba (Y). Hasil uji $F$ menunjukkan bahwa nilai $F$ Hitung 3,733 dengan tingkat signifikansi 0,000 lebih kecil dari 0,05 hal ini menunjukkan bahwa yaitu penjualan tunai dan penjualan kredit secara serentak
2. atau bersma-sama berpengaruh positif dan signifikan terhadap laba usaha dengan demikian hipotesis diterima.

3. Analisis Uji t dilakukan untuk melihat dan mengukur secara parsial pengaruh variabel bebas penjualan tunai dan penjualan kredit terhadap variabel terikat (Y). Hasil uji $t$ menunjukkan sebagai berikut: 
a. Variabel penjualan tunai (X1), nilai t Hitung 8,676 dengan tingkat signifikansi 0,000 lebih kecil dari 0,05 berarti penjualan tunai berpengaruh signifikan terhadap laba usaha pada Bengkel Las Diana di Palopo

b. Variabel penjualan kredit (X2), nilai t Hitung 6,418 dengan tingkat signifikansi 0,000 lebih kecil dari 0,05 berarti penjualan kredit berpengaruh signifikan terhadap laba usaha pada Bengkel Las Diana di Palopo

Maka dapat disimpulakan bahwa hasil Uji $t$ menunjukkan bahwa variabel bebas yaitu penjualan tunai memiliki pengaruh signifikan terhadap laba pada Bengkel Las Diana di Palopo

\section{SIMPULAN}

Berdasarkan hasil dan análisis maka ada beberapa kesimpulan yaitu:

1. Penelitian ini juga menunjukkan bahwa Variabel penjualan tunai, penjualan kredit berpengaruh signifikan terhadap laba usaha pada Bengkel Las Diana di Palopo

2. Hasil uji $F$ menunjukkan bahwa nilai $F$ hitung 3,733 dengan tingkat signifikansi 0,000 lebih kecil dari 0,05 (tabel 2,32) hal ini menunjukkan bahwa yaitu penjualan tunai dan penjualan kredit secara serentak atau bersma-sama berpengaruh positif dan signifikan terhadap laba usaha dengan demikian hipotesis diterima.
3. Nilai koefisien korelasi $(\mathrm{R})$ sebesar $88,8 \%$, hal ini menunjukkan bahwa hubungan antara variabel bebas yaitu penjualan tunai dan penjualan kredit terhadap variabel terikat yaitu laba Usaha $(Y)$ berkorelasi positif atau mempunyai hubungan yang kuat.

4. Nilai koefisien determinasi $\left(R^{2}\right)$ sebesar 0,789 menunjukkan bahwa pengaruh atau kontribusi variabel bebas terhadap variabel terikat sebesar $78,9 \%$ dan sisanya sebesar $21,10 \%$ dipengaruhi oleh faktor atau variabel lain yang tidak diteliti dalam penelitian ini

\section{SARAN}

1. Perlunya peningkatan penjualan tunai pada pada bengkel Las Diana, sehingga mampu meningkatkan laba perusahaan

2. Perlu mengurangi penjualan tunai karena dapat menghambat perputaran modal perusahaan.

3. Disarankan agar supaya menekan penjualan kredit dan meningkatkan penjualan tunai, demi untuk kontinyu dan berkesinambungan kegiatan perusahaan.

\section{DAFTAR PUSTAKA}

Agus Arwani, 2008, Sistem Manajemen Kinerja, Gramedia, Jakarta.

Agus Sartono, 1998. Manajemen Keuangan. Edisi ketiga

Mc. Leod. 2001. Dasar-dasar Analisis Laporan Keuangan. Cetakan pertama, Penerbit Rineka Cipta. Jakarta. 
Mulyadi, 2001. Analisis Kredit. Pionir Jaya Bandung.

Narko. 2007. Perencanaan dan Pengendalian. Penerbit Ghalia Indonesia.

Kasmir, 2002. Dasar-dasar Perbankan. PT. Raja Grafindo Persada. Jakarta.

Manullang 2005. Kinerja Keuangan, Edisi keempat, cetakan Kedua, Percetakan Liberty, Yogyakarta.

Martono dan Agus Haijito, 2002. Manajemen Keuangan. Ekonsia. Yogyakarta.

Riyanto Bambang, 1995. Dasar-Dasar Pembelanjaan Perusahaan, Edisi Ke 12, Badan Penerbit Gajah Mada, Yogyakarta. Keempat BPFE Yogyakarta.

Suyatmo dkk. 1990. Analisa Laporan Keuangan, Edisi keempat, cetakan Kedua, Percetakan Liberty, Yogyakarta.

Sinungan.1997 Intermediate Accounting. Cetakan Ke $\quad-7$ Edisi 7 Penerbit Fakultas Ekonomi Universitas Gadjah Mada, Yogyakarta.

Sopyan, Safitri. Harahap. 1998. Analisis Kredit atas Laporan Keuangan. Edisi pertama. PT. raja Grafgindo. Persada Jakarta.

Sudarsomo dan Edilius. 2004. Manajemen Koperasi Indonesia. Cetakan Ketiga, PT. Rineka Cipta. Jakarta.

Suad Husna. 1998. Manajemen Keuangan Teori dan Penerapannya. Edisi ke empat. BPFE Yogyakarta.

. 1998. Manajemen Keuangan Teori dan Penerapannya. Edisi ke empat. BPFE Yogyakarta.
Suyatno. Thomas. Dkk. 1990. Dasar-dasar Perkreditan. PT. Gramedia Jakarta.

Tinon, Yunianti, Ananda. 1998. Dasar-dasar Perkreditan. PT. Gramedia Jakarta.

Undang-undang no. 25 Tahun 2009. Tentang Perkoperasian Indonesia

Weston, Fred.J and Thomas E. Copeland, Manajemen Keuangan, Edisi Kedelapan, Erlangga, Jakarta.

Widjaja, 1995, Manajemen Keuangan, Edisi Revisi, Cetakan Kedua, Penerbit Andy, Yogyakarta. 